(c) American Dairy Science Association, 2006.

\title{
Time and Incidence of Ovulation and Conception Rates After Incorporating Estradiol Cypionate into a Timed Artificial Insemination Protocol
}

\author{
C. B. Sellars, ${ }^{*}$ J. C. Dalton, ${ }^{*}$ R. Manzo, ${ }^{*}$ J. Day,t and A. Ahmadzadeh ${ }^{\star 1}$ \\ *Animal and Veterinary Science Department, University of Idaho, Moscow 83844 \\ †Dairy Health Services, Jerome, ID 83338
}

\section{ABSTRACT}

Two experiments were conducted to determine the effect of estradiol cypionate (ECP), when incorporated into a conventional $\mathrm{GnRH}-\mathrm{PGF}_{2 \alpha}-\mathrm{GnRH}$ timed artificial insemination protocol (Ovsynch), on systemic estradiol $\left(\mathrm{E}_{2}\right)$, time and incidence of ovulation, luteal development, and conception rate in Holstein cows. Our objective was to determine if administration of $0.25 \mathrm{mg}$ of ECP at the time of the second GnRH injection would effectively synchronize ovulation and increase conception rate. In Experiment 1, lactating Holstein cows ( $\mathrm{n}=$ 23; $58.7 \pm 1.2 \mathrm{~d}$ in milk) were synchronized with $\mathrm{PGF}_{2 \alpha}$ (at $d-10$ ). Ten days later, Ovsynch was initiated with the administration of $100 \mu \mathrm{g}$ of $\mathrm{GnRH}(\mathrm{d} 0)$ followed by $\mathrm{PGF}_{2 \alpha}$ on $\mathrm{d} 7$. On $\mathrm{d}$ 9, cows were assigned randomly to be treated with either GnRH + $0.25 \mathrm{mg}$ of ECP (OVS$\mathrm{ECP} ; \mathrm{n}=11$ ) or $\mathrm{GnRH}$ and $1 \mathrm{~mL}$ of cottonseed oil (OVS$\mathrm{C} ; \mathrm{n}=12$ ). Ovarian activity was monitored by ultrasonography on $\mathrm{d} 0,7$, and 9 . To determine the time of ovulation, ultrasound examinations were conducted at 12 and $20 \mathrm{~h}$ posttreatment and then at least every $3 \mathrm{~h}$ until either $36 \mathrm{~h}$ posttreatment or ovulation was observed. Blood samples were collected on d 0, 7, 9, and 16 for progesterone analysis. Blood samples also were collected at the time of treatment $(\mathrm{d} 9,0 \mathrm{~h})$ and at 6 , 12,20 , and $28 \mathrm{~h}$ for $\mathrm{E}_{2}$ analysis. Incidence of ovulation did not differ between treatments. Mean ovulation time relative to the second $\mathrm{GnRH}$ administration was similar between treatments. Serum progesterone concentration did not differ between treatments at any time. Serum $\mathrm{E}_{2}$ concentration was not different at the time of treatment $(0 \mathrm{~h})$; however, mean $\mathrm{E}_{2}$ concentration was greater for the OVS-ECP group at 6 and $12 \mathrm{~h}$ after treatment compared with OVS-C. In Experiment 2, lactating dairy cows $(\mathrm{n}=333)$ in 3 commercial herds were randomly assigned to OVS-ECP $(\mathrm{n}=169)$ or OVS-C $(\mathrm{n}=$ 164). Cows were inseminated 22 to $24 \mathrm{~h}$ posttreatment.

Received May 17, 2005.

Accepted October 3, 2005.

${ }^{1}$ Corresponding author: amin@uidaho.edu
Conception rates did not differ between treatments. Estradiol cypionate treatment was successful in increasing serum $\mathrm{E}_{2}$ when administered at the time of the second dose of GnRH in the Ovsynch protocol. Conception rates, however, were not affected by treatment. Key words: timed artificial insemination, estradiol cypionate, conception rate

\section{INTRODUCTION}

Systematic breeding programs provide an organized and efficient approach to administering AI and improving reproductive efficiency in dairy herds. To alleviate the difficulties associated with detection of estrus and to increase the $\mathrm{AI}$ submission rate, timed $\mathrm{AI}$ programs have been developed such as Ovsynch (Pursley et al., 1995). Ovsynch (d $0 \mathrm{GnRH}, \mathrm{d} 7 \mathrm{PGF}_{2 \alpha}, \mathrm{d} 9 \mathrm{GnRH}$, timed AI 8 to $24 \mathrm{~h}$ ) was designed to synchronize ovulation, thereby allowing timed AI of all cows without detection of estrus. Synchronization of ovulation in 84 to $100 \%$ of cows can be expected (Pursley et al., 1995; Fricke et al., 1998; Vasconcelos et al., 1999; Cartmill et al., 2001). Conception rates following timed AI associated with Ovsynch range from 22 to $42 \%$ in dairy cows (Stevenson et al., 1996; Pursley et al., 1997a,b, 1998; Fricke et al., 1998; Jobst, 1998; Stevenson et al., 1999). In practice, although AI submission rates are $100 \%$ when using Ovsynch, conception rate may be reduced with this protocol compared with cows that receive AI following detected estrus (Stevenson et al., 1999; Santos et al., 2004). Nevertheless, pregnancy rate (AI submission or estrus-detection rate $\times$ conception rate) achieved either after timed AI or after detected estrus and AI may be comparable.

Although timed AI protocols such as Ovsynch are a convenient method to increase AI submission rate, a number of studies indicate mechanisms by which induction of ovulation by administration of $\mathrm{GnRH}$ during proestrus can disturb normal reproductive function and negatively affect conception rates. Lucy and Stevenson (1986) found that an injection of GnRH during periestrus, and before the preovulatory LH surge, decreased serum estradiol $\left(\mathbf{E}_{2}\right)$ and reduced fertility compared 
with cows having a spontaneous LH surge. These results are further supported by Kobayashi (1995) who showed that administration of $\mathrm{GnRH}$ after $\mathrm{PGF}_{2 \alpha}$ caused a cessation of estrogen secretion by the preovulatory follicle as evidenced by a decline in blood concentrations of $E_{2}$. Thatcher and Chenault (1976) reported that $\mathrm{GnRH}$ treatment of cattle $48 \mathrm{~h}$ after $\mathrm{PGF}_{2 \alpha}$ reduced the frequency of estrus compared with $\mathrm{PGF}_{2 \alpha}$-induced estrus alone. Those authors suggested that this observation might be due to alterations in plasma progestins and $\mathrm{E}_{2}$. In vitro studies (Uemura et al., 1994; Takekida et al., 2000) have shown that GnRH agonists directly inhibit ovarian and granulosa cell steroidogenesis $\left[\mathrm{E}_{2}\right.$ and progesterone $\left(\mathbf{P}_{4}\right)$ ]. Lower frequency of estrus in cows treated with $\mathrm{GnRH} 48 \mathrm{~h}$ after $\mathrm{PGF}_{2 \alpha}$ (Rodriguez et al., 1975; Thatcher and Chenault, 1976), taken together with suppressed estrual behavior following the second GnRH injection in cows subjected to Ovsynch (Pursley et al., 1995; Twagiramungu et al., 1995; Stevenson et al., 1996, 1999, and 2000; Jobst, 1998) as well as in vitro studies give further support to the premise that induction of ovulation during the follicular phase, as occurs with Ovsynch, suppresses $\mathrm{E}_{2}$ secretion. Further, exogenous $\mathrm{E}_{2}$ increases uterine contractions, efficiency of sperm transport, number of sperm in the oviducts, retention and adhesion of sperm to oviductal epithelium, enhances sperm capacitation and the true acrosome reaction, and increases fertilization (Hawk and Cooper, 1978; Hawk, 1983, 1987; Bathla et al., 1999; Langendijk et al., 2002). Consequently, conception rates observed following GnRH-induced ovulation and timed AI may not be optimized due, in part, to asynchronous timing of the GnRH-induced LH surge and final follicular maturation coupled with limited or brief $\mathrm{E}_{2}$ secretion around the time of estrus (Lucy and Stevenson, 1986; Stevenson et al., 1999; Taponen et al., 1999). Another factor potentially limiting conception rate in cows enrolled in the Ovsynch protocol (without presynchronization) might be due to a 16 to $19 \%$ lack of synchronization of ovulation after the second GnRH (Vasconcelos et al., 1999).

Our hypothesis was that administration of $0.25 \mathrm{mg}$ of estradiol cypionate (ECP) at the time of the second dose of GnRH in the Ovsynch protocol (OVS-ECP) would improve fertility compared with the conventional Ovsynch protocol (OVS-C). The objectives of these experiments were to determine the effect of $0.25 \mathrm{mg}$ of ECP when incorporated into a conventional Ovsynch protocol on systemic $\mathrm{E}_{2}$, time and incidence of ovulation, luteal development, and first-service AI conception rate in dairy cows.

\section{MATERIALS AND METHODS}

\section{Experiment 1}

Experiment 1 was conducted at the University of Idaho Dairy Center using 23 lactating Holstein cows
$(\mathrm{DIM}=58.7 \pm 1.3 \mathrm{~d})$. Mean $( \pm \mathrm{SD}) \mathrm{BW}$ was $664 \pm 92$ $\mathrm{kg}$ and mean $( \pm \mathrm{SD}) \mathrm{BCS}$ was $2.6 \pm 0.5$ (scale $=1$ to 5 , with 1 being emaciated and 5 being grossly overconditioned). Average 3.5\% FCM yield at the DHI test closest to the day of treatment was $41.1 \pm 10.2 \mathrm{~kg}$ (mean $\pm \mathrm{SD}$ ). Based on transrectal palpation by the herd veterinarian, experimental cows had no abnormalities of the reproductive tract at the initiation of the experiment.

Ovulation Synchronization and Treatment. On $\mathrm{d}-10$, estrous cycles of cows were presynchronized with an i.m. injection of $25 \mathrm{mg}$ of $\mathrm{PGF}_{2 \alpha}$ (Lutalyse; Pfizer Animal Health, New York, NY). On d 0, and after detection of a corpus luteum (CL) by transrectal ultrasonography (Sonovet $600,5-\mathrm{MHz}$ probe, Universal Ultrasound, Bedford Hills, NY), the Ovsynch protocol was initiated with a dose of GnRH (100 $\mu \mathrm{g})$ administered i.m. (Cystorelin; Merial, Athens, GA). Seven days later (d 7), all cows received (i.m.) $25 \mathrm{mg}$ of $\mathrm{PGF}_{2 \alpha}$ to regress the CL. Forty-eight hours after $\mathrm{PGF}_{2 \alpha}$ treatment (d 9), cows were assigned randomly to treatment $(\mathrm{n}=11$; OVS-ECP) or control ( $\mathrm{n}=12$; OVS-C). The OVS-ECP cows received (i.m.) GnRH (100 $\mu \mathrm{g})+0.25 \mathrm{mg}$ of ECP (Pharmacia Animal Health, Kalamazoo, MI), whereas the OVS-C cows received GnRH $(100 \mu \mathrm{g})+$ cottonseed oil $(1 \mathrm{~mL})$. The ECP was diluted in purified cottonseed oil (Sigma-Aldrich Corp., St. Louis, MO).

Ovarian Examination and Blood Collection. On d 0,7 , and 9 , ovaries were examined via transrectal ultrasonography and structures recorded. Time of ovulation after treatment (injection of $\mathrm{GnRH}$ or $\mathrm{GnRH}+$ ECP) was determined by ultrasonography that was conducted at 12 and $20 \mathrm{~h}$ after treatment and then at least every $3 \mathrm{~h}$ thereafter until either ovulation or 36 $\mathrm{h}$, whichever occurred first. Ovulation was defined as the disappearance of any antral follicle $\geq 10 \mathrm{~mm}$ in diameter at the time of an ultrasound examination compared with the previous ultrasound examination (Kaneko et al., 1991). Time of ovulation was defined as the number of hours from the time of treatment to the midpoint of the 2 examinations between which ovulation had occurred (Walker et al., 1996). On d 16, ultrasonographic examinations of the ovaries were performed to confirm the occurrence of ovulation, as evidenced by the presence of a CL.

On d $0,7,9$, and 16, coccygeal blood samples were collected for later measurement of $\mathrm{P}_{4}$ concentrations to determine the ovarian response to the hormonal treatments. Coccygeal blood samples were obtained at 0,6 , 12,20 , and $28 \mathrm{~h}$ after treatment to determine whether ECP induced a significant change in serum $\mathrm{E}_{2}$ compared with controls. Blood samples were immediately placed in ice and stored at $4^{\circ} \mathrm{C}$ for a minimum of $20 \mathrm{~h}$ to allow clotting. All samples were centrifuged at $4^{\circ} \mathrm{C}$ for $30 \mathrm{~min}$ 
at $2,750 \times g$. Serum was harvested and stored at $-20^{\circ} \mathrm{C}$ until assayed for $\mathrm{E}_{2}$ or $\mathrm{P}_{4}$.

Hormone Assays. Serum $\mathrm{E}_{2}$ concentrations were determined by radioimmunoassay as described by Perry et al. (1991) and was kindly performed by the laboratory of Matthew Lucy (University of Missouri, Columbia). The assay was conducted in nonequilibrium conditions and the standard curve and all samples were assayed in duplicate. Primary antiserum bound $35 \%$ of ${ }^{125} \mathrm{I}_{-} \mathrm{E}_{2}$ in the absence of unlabeled $\mathrm{E}_{2}$. Intra- and interassay coefficients of variation $(\mathbf{C V})$ were 9.3 and $5.5 \%$, respectively.

Serum $\mathrm{P}_{4}$ concentrations were determined using a solid-phase radioimmunoassay (Diagnostic Products Corp., Los Angeles, CA). The assay was conducted under equilibrium conditions. The standard curve ranged from 0.1 to $40 \mathrm{ng} / \mathrm{mL}$, and all samples were assayed in duplicate. Intraassay CV was $7.8 \%$.

\section{Statistical Analyses: Experiment 1}

Analysis of repeated measures using the mixed procedure of SAS (Littell et al., 1998) was used to analyze serum $\mathrm{E}_{2}$ data. The statistical model included treatment, the repeated factor time, and treatment $\times$ time interaction. Cow within treatment was designated as a random effect and pretreatment serum $\mathrm{E}_{2}$ values were used as covariates in the model.

Serum $\mathrm{P}_{4}$ data were analyzed by least squares ANOVA using the GLM procedure of SAS (SAS Inst. Inc., Cary, NC). The statistical model included treatment. Separate analyses were performed for each sampling day (d $0,7,9$, and 16$)$ to verify that cows in both treatments had similar $\mathrm{P}_{4}$ concentrations at the initiation of OvSynch and to determine ovarian response to the first $\mathrm{GnRH}$, second $\mathrm{PGF}_{2 \alpha}$, and second GnRH administrations.

\section{Experiment 2}

Experiment 2 was conducted to determine the effect of OVS-ECP on first-service conception rate in artificially inseminated dairy cows. Three commercial dairies in southern Idaho participated in a field trial. Three hundred thirty-three multiparous cows (OVS-ECP: $\mathrm{n}=$ 169; OVS-C: $\mathrm{n}=164$ ), having fewer than 80 DIM, were submitted for the first postpartum insemination for this experiment. Hormonal treatments were similar to those in Experiment 1, except that all cows received $\mathrm{PGF}_{2 \alpha}$ $14 \mathrm{~d}$ before the first dose of $\mathrm{GnRH}$ (d 0). Before $\mathrm{d} 9$, cows were assigned randomly to either OVS-ECP or OVS-C by the herd manager at each farm and without the knowledge of personnel who administered treatments. On each dairy, cows were inseminated approxi-
Table 1. Serum progesterone concentrations (ng/mL; least squares mean \pm SEM) on d $0,7,9$, and 16 in lactating Holstein cows treated with Ovsynch with and without estradiol cypionate (Experiment 1)

\begin{tabular}{lllll}
\hline & \multicolumn{5}{c}{ Day of experiment } \\
\cline { 2 - 6 } Treatment $^{1}$ & 0 & 7 & 9 & 16 \\
\hline OVS-ECP $(\mathrm{n}=11)$ & $3.0 \pm 0.8$ & $3.2 \pm 0.8$ & $0.5 \pm 0.3$ & $3.2 \pm 0.4$ \\
OVS-C $(\mathrm{n}=12)$ & $4.0 \pm 0.7$ & $4.8 \pm 0.8$ & $0.8 \pm 0.3$ & $3.1 \pm 0.3$ \\
\hline
\end{tabular}

${ }^{1}$ OVS-ECP $=$ Ovsynch was initiated with the administration of 100 $\mu \mathrm{g}$ GnRH ( $\mathrm{d} 0$ ) followed by $\mathrm{PGF}_{2 \alpha}$ on $\mathrm{d}$ 7. On d 9 cows received (i.m.) $\mathrm{GnRH}(100 \mu \mathrm{g})+0.25 \mathrm{mg}$ of estradiol cypionate (ECP); OVS-C = Ovsynch was initiated with the administration of $100 \mu \mathrm{g}$ of $\mathrm{GnRH}$ (d 0) followed by $\mathrm{PGF}_{2 \alpha}$ on $\mathrm{d} 7$. On d 9, cows received GnRH (100 $\left.\mu \mathrm{g}\right)$ + cottonseed oil (1 mL).

mately 22 to $24 \mathrm{~h}$ after treatment by a single inseminator. Cows in all 3 herds were observed for signs of estrus once daily based on tail chalk removal. Cows that exhibited estrus on or before d 9 received AI immediately and were removed from the experiment. Conception rates (number of confirmed pregnancies divided by number of cows inseminated) were calculated based upon pregnancy diagnosis by the herd veterinarian via palpation per rectum of uterine contents at 35 to $42 \mathrm{~d}$ after AI.

\section{Statistical Analyses: Experiment 2}

Conception rate data were analyzed using the Logistic procedure of SAS (SAS Inst.). The model included the effects of treatment, herd, and the treatment $\times$ herd interaction. Based on the number of cows used in this experiment, a $13 \%$ difference in conception rate could be detected. This sensitivity was calculated (Agresti, 1990) for $\alpha=0.07$ and $\beta=0.20$ and an average pregnancy rate of $30 \%$.

\section{RESULTS}

\section{Experiment 1}

Average BW and BCS did not differ between treatments. Mean daily 3.5\% FCM production was not different between treatments. Moreover, mean serum $\mathrm{P}_{4}$ concentrations did not differ between treatments at any time (Table 1).

A time $\times$ treatment interaction $(P<0.05)$ was detected for serum $\mathrm{E}_{2}$ concentrations. At $0 \mathrm{~h}$, mean serum $\mathrm{E}_{2}$ concentrations were $5.9 \pm 0.4 \mathrm{pg} / \mathrm{mL}$ for OVS-ECP cows and $5.3 \pm 0.3 \mathrm{pg} / \mathrm{mL}$ for OVS-C cows and did not differ (Figure 1). Mean serum $\mathrm{E}_{2}$ concentrations were different between treatments at $6(P<0.05)$ and $12 \mathrm{~h}(P=$ 0.05 ; Figure 1). At $6 \mathrm{~h}$ posttreatment, mean serum $\mathrm{E}_{2}$ concentration in OVS-ECP cows $(6.0 \pm 0.4 \mathrm{pg} / \mathrm{mL})$ was greater $(P<0.05)$ than that of OVS-C cows $(4.4 \pm 0.3 \mathrm{pg} /$ 


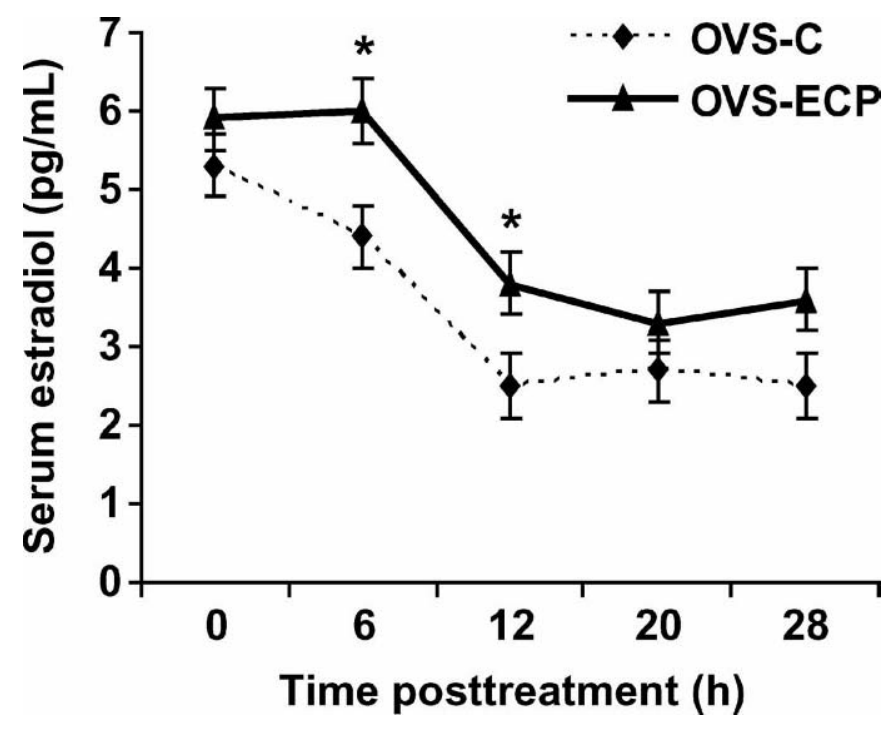

Figure 1. Mean serum concentrations of estradiol in cows treated with Ovsynch with (OVS-ECP) and without (OVS-C) estradiol cypionate injection coincident with the second GnRH injection of Ovsynch (Experiment 1). Treatment $(0 \mathrm{~h})$ with either $\mathrm{GnRH}$ or $\mathrm{GnRH}+$ estradiol cypionate occurred at $0 \mathrm{~h}$. ${ }^{*}$ Means differed $(P \leq 0.05)$ between treatments at 6 and $12 \mathrm{~h}$.

$\mathrm{mL}$; Figure 1). Mean serum $\mathrm{E}_{2}$ concentration declined in both groups between 6 and $12 \mathrm{~h}$ after treatment, but remained greater $(P=0.05)$ for the OVS-ECP cows than for the OVS-C cows at $12 \mathrm{~h}(3.77 \pm 0.36$ vs. $2.58 \pm 0.33$ $\mathrm{pg} / \mathrm{mL})$.

Time of ovulation did not differ between treatments (Table 2). Range in time of ovulation was 16 to $32 \mathrm{~h}$ and 26 to $29 \mathrm{~h}$ for the OVS-ECP and OVS-C cows, respectively. Incidence of ovulation did not differ and was $100 \%$ for OVS-ECP and $92 \%$ for OVS-C group. Mean diameter of the ovulatory follicle, measured at $20 \mathrm{~h}$ after treatment, was similar between groups (18.3 \pm 1.2 vs. $18.1 \pm 1.4 \mathrm{~mm}$; Table 2 ). In the present study, $82 \%$ of all observed ovulations were on the right ovary (18 of 22; Table 2).
On d 16, all cows were subjected to ultrasonographic ovarian examination of the ovaries and all had a CL on the ovary where ovulation had been previously detected. Mean serum $\mathrm{P}_{4}$ concentrations on $\mathrm{d} 16$ did not differ between groups and were $3.2 \pm 0.4$ and $3.1 \pm$ $0.3 \mathrm{ng} / \mathrm{mL}$ in the OVS-ECP and OVS-C, respectively (Table 1).

\section{Experiment 2}

Neither treatment, herd, nor treatment $\times$ herd interaction influenced conception rate. Overall conception rate for the OVS-ECP group was $31.4 \%$ and for the OVS-C group was $36.6 \%$ (Table 3 ).

\section{DISCUSSION}

\section{Experiment 1}

In the present study, serum $\mathrm{E}_{2}$ concentrations were greater in OVS-ECP cows at 6 and $12 \mathrm{~h}$ after ECP treatment compared with OVS-C cows (Figure 1). Taponen et al. (1999) found that when GnRH was administered $24 \mathrm{~h}$ after $\mathrm{PGF}_{2 \alpha}$ injection, serum $\mathrm{E}_{2}$ declined to basal concentrations within $1 \mathrm{~d}$. Mee et al. (1993) found that serum $\mathrm{E}_{2}$ declined after estrus in both saline- and GnRH-treated cows; however, serum $\mathrm{E}_{2}$ was less in the GnRH-treated group. Serum $E_{2}$ profiles in OVS-ECP cows differed from those in the OVS-C cows indicating that $0.25 \mathrm{mg}$ of ECP was able to alter circulating $\mathrm{E}_{2}$ in cows during the first $12 \mathrm{~h}$ after treatment (Figure 1).

Lucy and Stevenson (1986) administered GnRH or saline at $72 \mathrm{~h}$ after $\mathrm{PGF}_{2 \alpha}$ and found that $\mathrm{GnRH}$-treated cows had a mean serum $\mathrm{E}_{2}$ concentration approximately $3 \mathrm{pg} / \mathrm{mL}$ less than that of saline-treated cows. In the present study, serum $\mathrm{E}_{2}$ in OVS-C group was $36 \%$ less at $6 \mathrm{~h}$ after $\mathrm{GnRH}$ administration compared with that in the OVS-ECP group. Serum $\mathrm{E}_{2}$ profile of the OVS-C group might suggest that the time of $\mathrm{GnRH}$ administration was asynchronous with the natural timing of neuroendocrine events following $\mathrm{PGF}_{2 \alpha}$; thus, the

Table 2. Time and incidence of ovulation, and size of ovulatory follicle in lactating Holsteins treated with Ovsynch with and without estradiol cypionate (Experiment 1)

\begin{tabular}{|c|c|c|c|c|}
\hline Treatment $^{1}$ & $\begin{array}{l}\text { Time of } \\
\text { ovulation, }{ }^{2} \mathrm{~h}\end{array}$ & $\begin{array}{l}\text { Incidence of } \\
\text { ovulation, \% }\end{array}$ & $\begin{array}{l}\text { Diameter of } \\
\text { ovulatory } \\
\text { follicle, }{ }^{2} \\
\mathrm{~mm}\end{array}$ & $\begin{array}{l}\text { Right } \\
\text { ovary } \\
\text { ovulation } \\
\%\end{array}$ \\
\hline OVS-ECP $(\mathrm{n}=11)$ & $26 \pm 1$ & 100 & $18.3 \pm 1.2$ & 82 \\
\hline OVS-C $(\mathrm{n}=12)$ & $27 \pm 1$ & 92 & $18.1 \pm 1.5$ & 83 \\
\hline
\end{tabular}

${ }^{1}$ OVS-ECP $=$ Ovsynch was initiated with the administration of $100 \mu \mathrm{g} \mathrm{GnRH} \mathrm{(d} \mathrm{0)} \mathrm{followed} \mathrm{by} \mathrm{PGF} \mathrm{P}_{2 \alpha}$ on d 7. On d 9 cows received (i.m.) GnRH $(100 \mu \mathrm{g})+0.25 \mathrm{mg}$ of estradiol cypionate (ECP); OVS-C = Ovsynch was initiated with the administration of $100 \mu \mathrm{g}$ of $\mathrm{GnRH}$ (d 0) followed by $\mathrm{PGF}_{2 \alpha}$ on $\mathrm{d}$ 7. On $\mathrm{d}$ 9, cows received GnRH $(100 \mu \mathrm{g})+$ cottonseed oil $(1 \mathrm{~mL})$.

${ }^{2}$ Means \pm SE. 
Table 3. Conception rate (number of pregnant cows/total number of cows inseminated) in lactating Holstein cows treated with Ovsynch with and without estradiol cypionate (Experiment 2)

\begin{tabular}{lll}
\hline & \multicolumn{3}{c}{ Treatment $^{1}$} \\
\cline { 2 - 4 } Herd & OVS-ECP & OVS-C \\
\cline { 2 - 3 } 1 & $29.4(51)$ & $40.4(47)$ \\
2 & $33.9(56)$ & $38.6(57)$ \\
3 & $30.6(62)$ & $31.7(60)$ \\
Total & $31.4(169)$ & $36.6(164)$ \\
\hline
\end{tabular}

${ }^{1}$ OVS-ECP $=$ Ovsynch was initiated with the administration of 100 $\mu \mathrm{g}$ GnRH (d 0) followed by $\mathrm{PGF}_{2 \alpha}$ on $\mathrm{d} 7$. On d 9 cows received (i.m.) GnRH $(100 \mu \mathrm{g})+0.25 \mathrm{mg}$ of estradiol cypionate (ECP); OVS-C = Ovsynch was initiated with the administration of $100 \mu \mathrm{g}$ of $\mathrm{GnRH}$ (d 0) followed by $\mathrm{PGF}_{2 \alpha}$ on d 7. On d 9, cows received GnRH (100 $\left.\mu \mathrm{g}\right)$ + cottonseed oil $(1 \mathrm{~mL})$.

preovulatory follicle may not have matured adequately before the GnRH-induced LH surge as originally hypothesized by Lucy and Stevenson (1986).

Ovulations in both groups occurred between 16 and $32 \mathrm{~h}$ after GnRH administration (Table 2), which is comparable to findings of other researchers (Pursley et al., 1995; Ahmadzadeh et al., 2002). Time of ovulation in our study was similar to that after spontaneous estrus $(27.9 \pm 5.6 \mathrm{~h}$ after the onset of estrus; Walker et al., 1996).

The greater $\mathrm{E}_{2}$ concentration observed in the OVSECP compared with OVS-C group was not related to size of the ovulatory follicle, because no difference in mean diameter of the ovulatory follicle was detected between groups at 20-h posttreatment. Results for both groups are comparable to those described by Ahmadzadeh et al. (2002) in which mean diameter of the ovulatory follicle was $18.6 \pm 3.2 \mathrm{~mm}$. Similarly, Vasconcelos et al. (1999) measured the ovulatory follicle at the time of the second dose of GnRH in Ovsynch-treated cattle and reported the size of the ovulatory follicle to be $18.24 \mathrm{~mm}$.

\section{Experiment 2}

Despite studies that have reported that exogenous $\mathrm{E}_{2}$ increases uterine contractions, efficiency of sperm transport, number of sperm in the oviducts, total number of sperm retained in the female reproductive tract, and proportion of total ova fertilized in laboratory animals and livestock (Hawk and Cooper, 1978; Hawk, 1983; Bathla et al., 1999; Orihuela et al., 1999; Langendijk et al., 2002), no difference in conception rate was detected between OVS-ECP and OVS-C groups. For 333 dairy cows in 3 different herds, the conception rates were similar (Table 3). Based on the number of cows used in this experiment, a 13 percentage-point differ- ence in conception rate could be detected. This sensitivity was calculated (Agresti, 1990) for $\alpha=0.07$ and $\beta=$ 0.20 with an average pregnancy rate of $30 \%$. The probability of detecting a smaller difference in conception rate between treatments in this experiment was limited by the number of cows enrolled.

In contrast, Cerri et al. (2004) reported that use of 1 $\mathrm{mg}$ of ECP to induce ovulation as part of a timed AI protocol improved conception at first postpartum insemination in dairy cows. It is possible that increased conception rates observed for cows in the Heatsynch protocol are the result of prolonged exposure to greater concentrations of estradiol during proestrus (Cerri et al., 2004). It has been proposed that estradiol during proestrus influences sperm transport and might inhibit $\mathrm{PGF}_{2 \alpha}$ secretion in the subsequent estrous cycle (Mann and Lamming, 2000).

Serum $\mathrm{E}_{2}$ for the OVS-ECP group was greater during the first $12 \mathrm{~h}$ posttreatment (Figure 1). Nevertheless, no difference in conception rate was detected between treatments in Experiment 2. One possible explanation for the similarity in conception rate between treatments was the timing of $\mathrm{AI}$ in relation to ECP administration and the systemic $\mathrm{E}_{2}$ profile. Cows in Experiment 2 were inseminated 22 to $24 \mathrm{~h}$ after ECP, and not likely during the time of maximally elevated serum $\mathrm{E}_{2}$ (Figure 1). Therefore, although the OVS-ECP cows were exposed to greater serum concentrations of $\mathrm{E}_{2}$ than OVS-C cows during the first $12 \mathrm{~h}$ posttreatment, by the time of $\mathrm{AI}$ serum $\mathrm{E}_{2}$ concentrations in most cows in the OVS-ECP group had likely declined to concentrations similar to the OVS-C group. Furthermore, it is likely that sperm capable of fertilization did not reach the ampullaryisthmus junction (site of fertilization) until 29 to $32 \mathrm{~h}$ posttreatment (on average), a time when the 2 groups were likely not different with regard to serum $\mathrm{E}_{2}$. In a similar experiment using beef cattle, Ahmadzadeh et al. (2003) reported that conception rate tended to improve (68 vs. $57 \%$, for OVS-ECP compared with OVSC groups, respectively) when AI was performed 6 to 8 $\mathrm{h}$ after GnRH + ECP, which corresponds to the time of maximally elevated serum estradiol in OVS-ECP cows in the current study. This may indicate that greater $\mathrm{E}_{2}$ in the OVS-ECP when timed AI was performed enhanced uterine activity, sperm transport, or fertilization rates as previously suggested (Hawk and Cooper, 1978; Bathla et al., 1999; Langendijk et al., 2002).

\section{CONCLUSIONS}

Treatment with ECP at the time of the second dose of GnRH in the Ovsynch protocol successfully increased serum $\mathrm{E}_{2}$ in dairy cows. However, incorporating ECP into the Ovsynch protocol had no effect on conception 
rates. More research needs to be conducted in dairy cattle to further explore the role of increased $\mathrm{E}_{2}$ during proestrus on fertility.

\section{ACKNOWLEDGMENTS}

The authors express their appreciation to owners of participating dairy herds in southern Idaho and thank Pfizer Animal Health (New York, NY) for donation of Lutalyse, Pharmacia Animal Health (Kalamazoo, MI) for the ECP, and Merial for supplying the Cystorelin. The research was also supported, in part, by the Idaho Agricultural Experiment Station Hatch Formula Funding.

\section{REFERENCES}

Agresti, A. 1990. Sample size and power considerations. Page 239 in Categorical Data Analysis. John Wiley \& Sons, New York, NY.

Ahmadzadeh, A., D. G. Falk, R. Manzo, C. B. Sellars, and J. C. Dalton. 2003. Effect of incorporation of a low dose of estradiol cypionate (ECP) into a timed artificial insemination protocol on estrous behavior and conception rates in beef cattle. J. Anim. Sci. 81(Suppl. 1):180. (Abstr.)

Ahmadzadeh, A., R. Manzo, C. B. Sellars, L. E. Palmer, and R. L. Nebel. 2002. The efficacy of a reduced dose of GnRH on ovulation rate and time of ovulation in Jersey and Holstein dairy cows. J. Anim. Sci. 80(Suppl. 1):306-307. (Abstr.)

Bathla, H., S. S. Guraya, and G. K. Sangha. 1999. Role of estradiol in the capacitation and acrosome reaction of hamster epididymal spermatozoa in the isolated uterus of mice incubated in vitro. Indian J. Physiol. Pharmacol. 43:211-217.

Cartmill, J. A., S. Z. El-Zarkouny, B. A. Hensley, G. C. Lamb, and J. S. Stevenson. 2001. Stage of cycle, incidence, and timing of ovulation, and pregnancy rates in dairy cattle after three timed breeding protocols. J. Dairy Sci. 84:1051-1059.

Cerri, R. L., J. E. Santos, S. O. Juchem, K. N. Galvao, and R. C. Chebel. 2004. Timed artificial insemination with estradiol cypionate or insemination at estrus in high-producing dairy cows. J. Dairy Sci. 87:3704-3715.

Fricke, P. M., J. N. Guenther, and M. C. Wiltbank. 1998. Efficacy of decreasing the dose of GnRH used in a protocol for synchronization of ovulation and timed $\mathrm{AI}$ in lactating dairy cows. Theriogenology 50:1275-1284.

Hawk, H. W. 1983. Sperm survival and transport in the female reproductive tract. J. Dairy Sci. 66:2645-2660.

Hawk, H. W. 1987. Transport and fate of spermatozoa after insemination of cattle. J. Dairy Sci. 70:1487-1503.

Hawk, H. W., and B. S. Cooper. 1978. Increased retention of sperm in the reproductive tract and improved ovum fertilization after administration of estradiol to estrous rabbits. Biol. Reprod. $17: 850-857$.

Jobst, S. M. 1998. Evaluation of systematic breeding programs in lactating dairy cows. M.S. Thesis, Virginia Polytechnic Institute and State University, Blacksburg.

Kaneko, H., T. Terada, K. Taya, G. Watanabe, S. Sasamoto, Y. Hasegawa, and M. Igarashi. 1991. Ovarian follicular dynamics and concentrations of oestradiol-17 beta, progesterone, luteinizing hormone and follicle stimulating hormone during the periovulatory phase of the oestrous cycle in the cow. Reprod. Fertil. Dev. 3:529-535.

Kobayashi, Y. 1995. Gonadotropin-releasing hormone at estrous in the bovine: Changes in characteristics of the preovulatory follicle and corpus luteum and in vitro production of progesterone and oxytocin. M.S. Thesis, Kansas State University, Manhattan.

Langendijk, P., E. G. Bouwman, N. M. Soede, M. A. M. Taverne, and B. Kemp. 2002. Myometrial activity around estrous in sows:
Spontaneous activity and effects of estrogens, cloprostenol, seminal plasma, and clenbuterol. Theriogenology 57:1563-1577.

Littell, R. C., P. R. Henry, and C. B. Ammerman. 1998. Statistical analysis of repeated measures data using SAS. J. Anim. Sci. 76:1216-1231.

Lucy, M. C., and J. S. Stevenson. 1986. Gonadotropin-releasing hormone at estrous: Luteinizing hormone, estradiol, and progesterone during the periestrual and post insemination periods in dairy cattle. Biol. Reprod. 35:300-311.

Mann, G. E., and G. E. Lamming. 2000. The role of sub-optimal preovulatory oestradiol secretion in the aetiology of premature luteolysis during the short oestrous cycle in the cow. Anim. Reprod. Sci. 64:171-180.

Mee, M. O., J. S. Stevenson, B. M. Alexander, and R. G. Sasser. 1993. Administration of $\mathrm{GnRH}$ at estrous influences pregnancy rates, serum concentrations of LH, FSH, estradiol-17 $\beta$, pregnancy-specific protein $\mathrm{B}$, and progesterone, proportion of luteal cell types, and in vitro production of progesterone in dairy cows. J. Anim. Sci. 71:185-198.

Orihuela, P. A., M. E. Ortiz, and H. B. Croxatto. 1999. Sperm migration into and through the oviduct following artificial insemination at different stages of the estrous cycle in the rat. Biol. Reprod. 60:908-913.

Perry, R. C., L. R. Corah, G. H. Kiracofe, J. S. Stevenson, and W. E. Beal. 1991. Endocrine changes and ultrasonography of ovaries in suckled beef cows during resumption of postpartum estrous cycles. J. Anim. Sci. 69:2548-2555.

Pursley, J. R., M. R. Kosorok, and M. C. Wiltbank. 1997a. Reproductive management of lactating dairy cows using synchronization of ovulation. J. Dairy Sci. 80:301-306.

Pursley, J. R., M. O. Mee, and M. C. Wiltbank. 1995. Synchronization of ovulation in dairy cattle using $\mathrm{PGF}_{2 \alpha}$ and GnRH. Theriogenology 44:915-923.

Pursley, J. R., R. W. Silcox, and M. C. Wiltbank. 1998. Effect of time of artificial insemination on pregnancy rates, calving rates, pregnancy loss, and gender ratio after synchronization of ovulation in lactating dairy cows. J. Dairy Sci. 81:2139-2144.

Pursley, J. R., M. C. Wiltbank, J. S. Stevenson, J. S. Ottobre, H. A. Garverick, and L. L. Anderson. 1997b. Pregnancy rates per artificial insemination for cows and heifers inseminated at a synchronized ovulation or synchronized estrous. J. Dairy Sci. 80:295-300.

Rodriguez, T. R., M. J. Field, W. C. Burns, D. E. Frank, J. F. Henges, W. W. Thatcher, and A. C. Warnick. 1975. Breeding at predetermined time in bovine following $\mathrm{PGF}_{2 \alpha}+\mathrm{GnRH}$. J. Anim. Sci. 40:188. (Abstr.)

Santos, J. E. P., S. O. Juchem, R. L. A. Cerri, K. N. Galvão, R. C. Chebel, W. W. Thatcher, C. Dei, and C. Bilby. 2004. Effect of bST and reproductive management on reproductive and lactational performance of Holstein dairy cows. J. Dairy Sci. 87:868-881.

Stevenson, J. S., Y. Kobayashi, M. P. Shipka, and K. C. Rauchholz. 1996. Altering conception of dairy cattle by gonadotropin-releasing hormone preceding luteolysis induced by prostaglandin $\mathrm{F}_{2 \alpha}$. J. Dairy Sci. 79:402-410.

Stevenson, J. S., Y. Kobayashi, and K. E. Thompson. 1999. Reproductive performance of dairy cows in various programmed breeding systems including OvSynch and combinations of gonadotropinreleasing hormone and prostaglandin F2 alpha. J. Dairy Sci. 82:506-515.

Stevenson, J. S., K. E. Thompson, W. L. Forbes, G. C. Lamb, D. M Grieger, and L. R. Corah. 2000. Synchronizing estrus and(or) ovulation in beef cows after combinations of $\mathrm{GnRH}$, norgestomet, and prostaglandin $\mathrm{F}_{2 \alpha}$ with or without timed insemination. J. Anim. Sci. 78:1747-1758.

Takekida, S., J. Deguchi, T. Samoto, H. Matsuo, and T. Maruo. 2000. Comparative analysis of the effects of gonadotropin-releasing hormone agonist on the proliferative activity, apoptosis, and steroidogenesis in cultured porcine granulosa cells at varying stages of follicular growth. Endocrine 12:61-67. 
Taponen, J., T. Katila, and H. Rodríguez-Martínez. 1999. Induction of ovulation with gonadotropin-releasing hormone during proestrus in cattle: Influence on subsequent follicular growth and luteal function. Anim. Reprod. Sci. 55:91-105.

Thatcher, W. W., and J. R. Chenault. 1976. Reproductive physiological responses of cattle to exogenous prostaglandin $\mathrm{F}_{2 \alpha}$. J. Dairy Sci. 59:1366-1375.

Twagiramungu, H., L. A. Guilbault, and J. J. Dufour. 1995. Synchronization of ovarian follicular waves with a gonadotropin-releasing hormone agonist to increase the precision of estrous in cattle: A review. J. Anim. Sci. 73:3141-3151.
Uemura, T., T. Namiki, A. Kimura, T. Yanagisawa, and H. Minaguchi. 1994. Direct effects of gonadotropin-releasing hormone on the ovary in rats and humans. Horm. Res. 41(Suppl. 1):7-13.

Vasconcelos, J. L. M., R. W. Silcox, G. J. M. Rosa, J. R. Pursley, and M. C. Wiltbank. 1999. Synchronization rate, size of the ovulatory follicle, and pregnancy rate after synchronization of ovulation beginning on different days of the estrous cycle in lactating dairy cows. Theriogenology 52:1067-1078.

Walker, W. L., R. L. Nebel, and M. L. McGilliard. 1996. Time of ovulation relative to mounting activity in dairy cattle. J. Dairy Sci. 79:1555-1561. 